\title{
THE ABSORPTION, EXCRETION, AND PHYSIOLOGICAL EFFECT OF IODINE IN NORMAL HUMAN SUBJECTS
}

\author{
By NORTON NELSON, EDWARD D. PALMES, CHARLES R. PARK, PATRICIA P. \\ WEYMOUTH, AND WILLIAM B. BEAN
}

(From the Armored Medical Research Laboratory, Fort Knox, Kentucky)

(Received for publication October 13, 1946)

Although iodine has been used as a therapeutic agent for many years, information concerning its absorption, excretion, and physiological effect in normal men is not extensive. Several investigators have studied the uptake of iodine in the normal and pathological thyroid $(1,2,3,4,5)$ and others, in balance studies, have sought to measure the daily iodine requirement of the body as a whole $(6,7,8,9)$. In general, very small amounts of iodine were used in these studies and the results cannot be applied readily to the fate of large quantities of iodine. This study deals with the absorption and excretion of iodine in quantities ranging from $20 \mathrm{mgm}$. to $440 \mathrm{mgm}$. per day, more than a thousand times the estimated daily requirement $(4,10)$, but within the range of clinical administration for syphilis, roentgenography, and for use as an expectorant, and only slightly above the commonly administered dosage of Lugol's solution for the treatment of thyroid disorders (11).

Two toxic effects of iodine in normal human subjects are well known, the direct toxic action of free iodine in aqueous or alcoholic solution on tissue protoplasm, and iodism or iodine sensitiveness, occurring in a small percentage of cases $(12,13$, 14). It was formerly thought that iodine could give rise at times to hyperthyroidism $(15,16,17)$, but more recently the consensus is that iodine has no effect on the basal metabolic rate of normal persons $(4,18,19,20,21)$. Studies in this regard, however, have been limited. The few subjects used were not closely observed or were not followed for more than one or two weeks. Iodized salt has been used in large population groups without ill effect (22) but the amount of the halogen ingested daily was very small. In rabbits, a fall in metabolism due to Lugol's solution has been noted, reaching minimum values on the third day, and followed by a return to normal (23). Other animal studies have been equivocal in this regard $(24,25,26,27,28)$. Iodine has been thought to increase nitrogen excretion in dogs and in man. (29).

In the present study a group of 13 healthy soldiers ingested large quantities of water containing an average of $34.8 \mathrm{mgm}$. per liter of iodine over a period of 38 days. $^{1}$ Iodine absorption from the gastrointestinal tract, excretion in the urine, sweat, and feces, and the concentration of iodine in the plasma were determined. A rough balance study was possible. The subjects worked and lived throughout the test in a hot humid environment. This led to the consumption of large amounts of iodine containing water and facilitated the study of iodine excretion in the sweat. The men were subjected to severe physical stress and observations were made on general health, work performance, acclimatization to heat, and basal metabolic rate.

\section{METHODS}

Experimental conditions. The subjects were divided into groups $\mathrm{A}$ and $\mathrm{B}$, of 3 and 10 men respectively, on the basis of physical characteristics and work performance during a preliminary control period of 6 days. The environmental temperature at this time was kept at 80 degrees F. dry bulb and 30 to 50 per cent relative humidity. The test period in which iodine was administered followed immediately and lasted 45 days. During this time the environment of the laboratory room was maintained at a dry bulb temperature of 90 to 91 degrees $F$. and 95 per cent relative humidity from 8:00 A.M. to 4:30 P.M., but was returned to the relatively cool environment of the control period in the remaining hours of the day and night. The test period was followed by a final control

1 This report is derived from a study of Bursoline, an iodine-containing agent for the disinfection of water. A Bursoline tablet contains $8.2 \mathrm{mgm}$. of free iodine and $8.2 \mathrm{mgm}$. of iodine combined as diglycine hydroiodide. On addition to water Bursoline yields a solution of free and ionic iodine. 
period of 3 days, identical with the first period. All men, unless incapacitated, walked 5 hours each day except Sunday, 3 hours in the morning and 2 hours in the afternoon, at an average pace of 2.8 miles per hour. They wore shorts and regulation army shoes only, and carried 20-pound packs. They remained in the laboratory room day and night.

Group B drank iodine-containing water in the first 38 days of heat exposure while group A drank salted tap water. During the last 6 days of heat exposure, group A drank iodine-containing water and group B drank salted tap water (Table I). On Sundays when the men did not work, water requirements were low and the iodine ingestion consequently was reduced.

The final iodine content of the drinking water averaged $34.8 \mathrm{mgm}$. per liter of which 34 per cent was free iodine and 66 per cent iodide.
TABLE I

Regimen of exposure to iodine and heat

\begin{tabular}{c|c|c|c|c|c}
\hline & $\begin{array}{c}\text { Cool } \\
\text { control } \\
6 \text { days }\end{array}$ & \multicolumn{2}{|l|}{ Iodine and moist heat 45 days } & $\begin{array}{c}\text { Cool } \\
\text { control } \\
3 \text { days }\end{array}$ \\
\cline { 2 - 6 } & $\begin{array}{c}\text { Days 6 6 } \\
\text { through } \\
1\end{array}$ & $\begin{array}{c}\text { Days 1 } \\
\text { through } \\
38\end{array}$ & Day 39 & $\begin{array}{c}\text { Days 40 } \\
\text { through } \\
45\end{array}$ & $\begin{array}{c}\text { Days 46 } \\
\text { through } \\
48\end{array}$ \\
\hline Group A & $\mathrm{T}$ & $\mathrm{S}$ & $\mathrm{S}$ & $\mathrm{I} \& \mathrm{~S}$ & $\mathrm{~T}$ \\
Group B & $\mathrm{T}$ & $\mathrm{I} \& \mathrm{~S}$ & $\mathrm{~S}$ & $\mathrm{~S}$ & $\mathrm{~T}$ \\
\hline
\end{tabular}

$\mathrm{T}=$ Tap water, untreated.

$\mathrm{S}=$ Tap water, salted to 0.1 per cent.

I \& $\mathrm{S}=$ Iodine water, salted to 0.1 per cent.

Experimental procedures. All water was dispensed by a trained technician and the consumption recorded. Twenty-four hour urine collections were made on all subjects throughout the study. During the period of iodine intake, blood samples were obtained on Monday morning and afternoon,

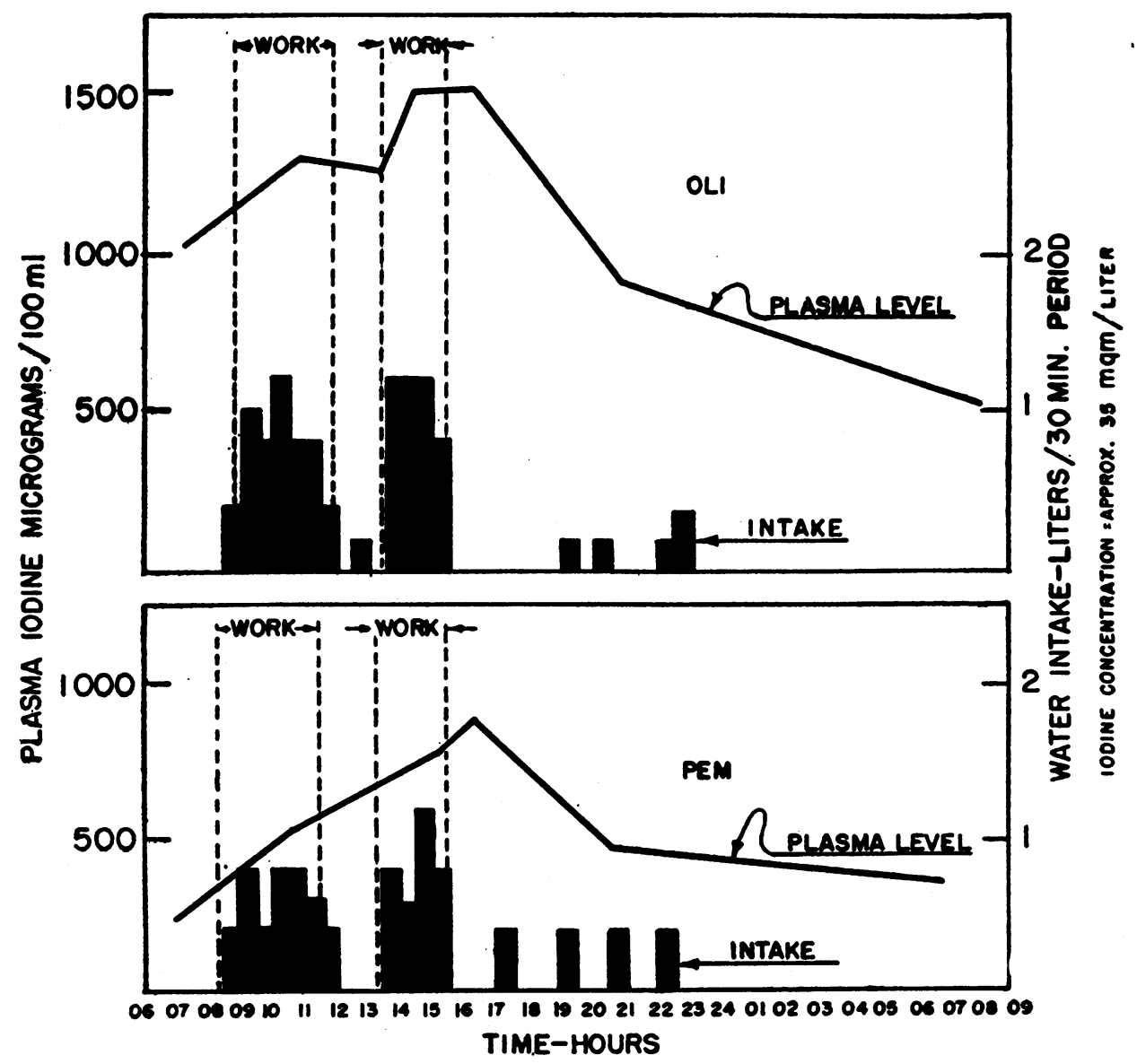

Fig. 1. Plasma Iodine versus Iodine Water Intake 
Wednesday afternoon, and Saturady morning and afternoon. After stopping iodine, only morning specimens were collected. Sweat collections were made at intervals by using dry suits of clothing for total sweat, or arm length rubber gauntlets for arm sweat. Feces were collected from 2 men for 7 consecutive days.

Details of the chemical methods will be given in a separate report (30).

Plasma rather than whole blood was chosen for analysis because of the simplified technic of determination and the expectation that, since the distribution of the iodide ion is similar to that of chloride (31), the plasma would give a more stable index of iodide concentration than whole blood. In addition, since the protein bound and organic iodine are removed with the protein precipitate $(32,33)$ a protein-free filtrate provided a homogeneous source of iodide ion. The available evidence (33) indicates that ingestion of iodine or iodide primarily influences the ionic iodide fraction of plasma. Iodine present in body fluids is believed to exist exclusively in the reduced form. This is suggested both by the redox potential of these fluids and by demonstration (34) that iodine is absorbed only after reduction to iodide. Unless iodine or iodides are being taken, only minute amounts of ionic iodide are found in plasma (4), certainly less than 3 or $4 \mu \mathrm{g}$. per $100 \mathrm{ml}$. which is the lower limit of detection by the method of analysis used here.

During the 38 days in which Group A drank salted tap water, the plasma collected from these men was uniformly negative for iodine (less than $10 \mu \mathrm{g}$. per $100 \mathrm{ml}$.); in four instances small amounts of iodine were found in the urine (probably contamination), but otherwise all were negative.

Observations were made on flushing, vigor, alertness, and the general reaction of subjects to work in the heat. Symptoms of headache, dizziness, nausea, palpitation, and gastrointestinal cramps were noted. Pulse rates and rectal temperatures were taken before, during, and after the periods of work. Sweat loss was calculated from the weight difference between the beginning and end of work periods, corrected for water intake, urine output, and sweat unevaporated at the time of weighings. Blood pressures were noted at frequent intervals.

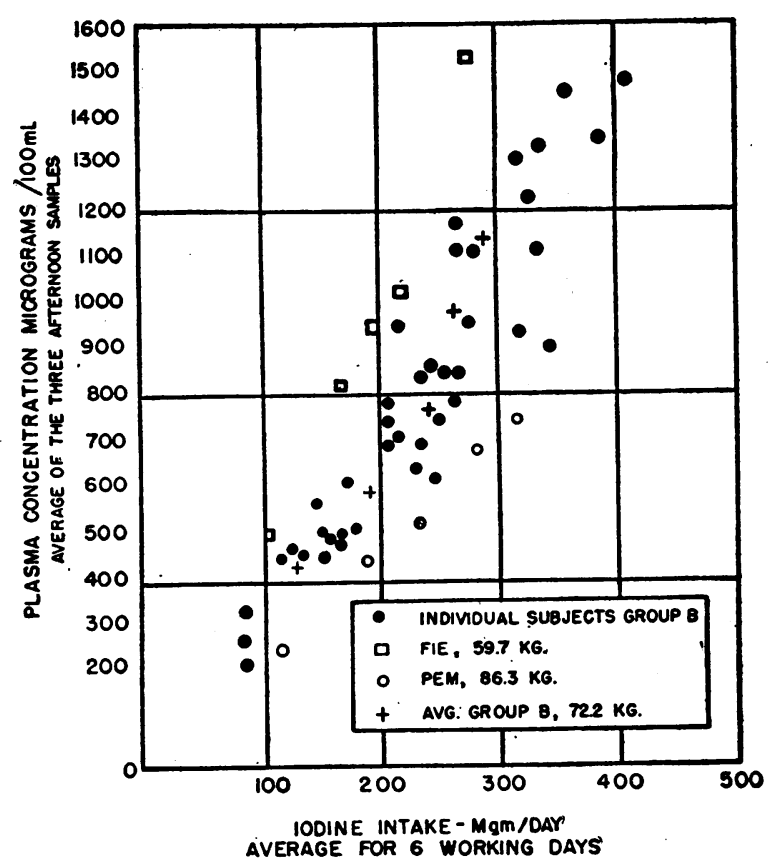

Fig. 2. Relationship Between Iodine Intake and Plasma Iodine Concentration (Group B)

Basal metabolism was measured by the closed circuit Sanborn Waterless and Benedict-Roth machines. The tests were made before 8:00 A.M. when the subjects with rare exceptions had not moved from their cots. Twenty determinations were made on each subject, 13 of them in the period of exposure to iodine and heat.

\section{RESULTS}

Absorption of iodine. Iodine was rapidly absorbed from the gastrointestinal tract. This is apparent in Figure 1 in which iodine ingested and plasma iodine concentrations are plotted as functions of time. A rise of plasma level occurred after each period of iodine intake. The dip in the climbing portion of the plasma concentration curve which appeared in subject Oli indicated that within a period of 1 to 2 hours after cessation of intake the peak of absorption had been passed. Absorption was complete since no significant quantity of iodine was recovered from the stools of the subjects on high intakes. The level of plasma iodine was directly related to the intake as is best seen in Figure 2.

This proportionality over longer periods of time appears in Figure 3 where plasma concentrations 

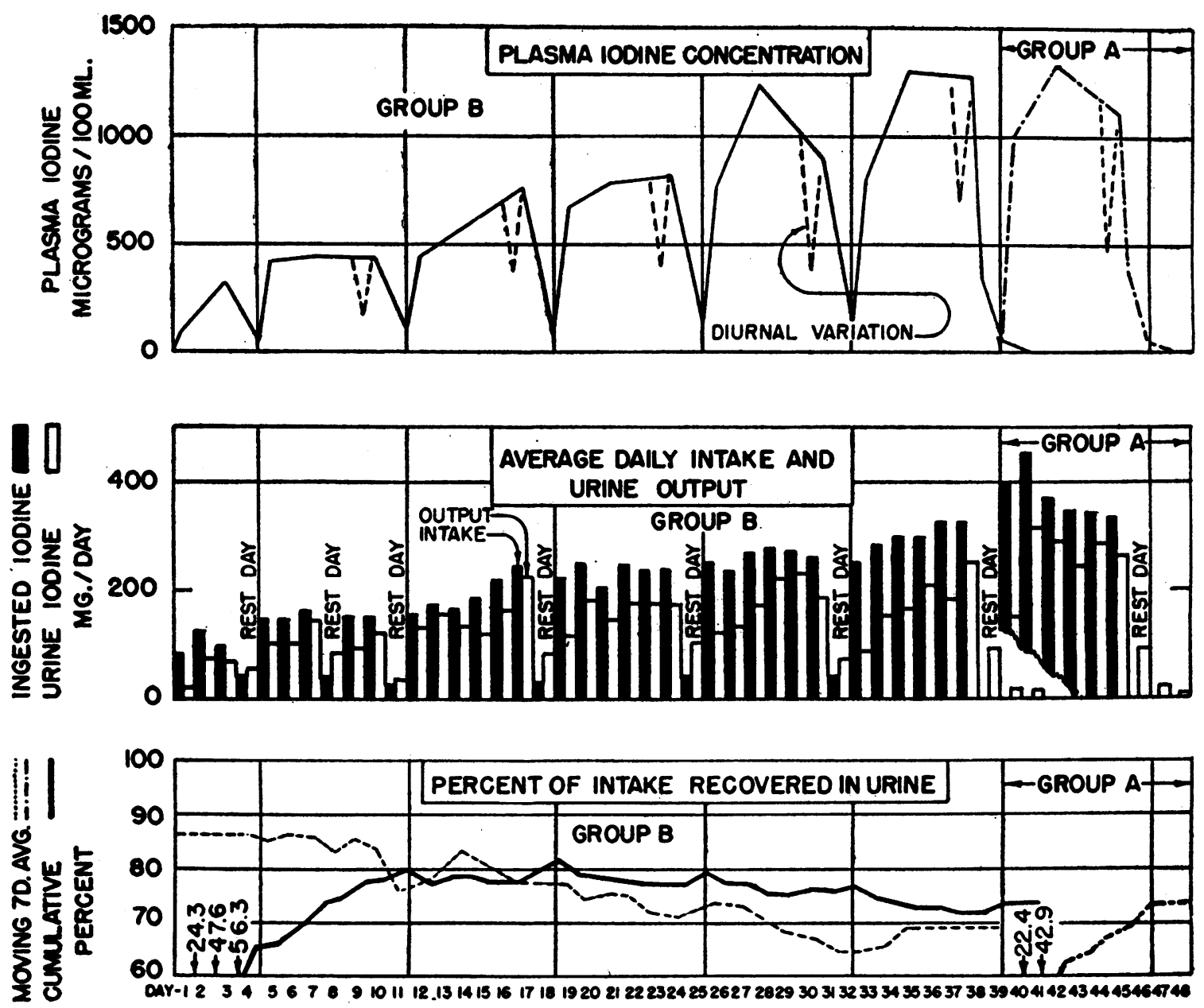

Fig. 3. Plasma Iodine Concentration, Iodine Intake, and Urine Output (Group A-Average of 3 Men; Group B-Average of $10 \mathrm{MeN}$ )

are shown in the upper panel, and intakes, plotted as solid columns for individual days, appear in the middle panel. The broken lines extending as V's from the solid envelope of plasma concentrations indicate the extent of diurnal variation.

Excretion of iodine. The uniformity and rapidity of the disappearance of iodine from the plasma are indicated in Figure 4 where iodine level is plotted on semilogarithmic scale against time. The linear plots suggest that a uniform rate of disappearance, proportional to the concentration, prevails during the elimination of iodine. From the slope of the average line, it is seen that if no more iodine is taken, plasma iodine concentration falls by 83 per cent (to 17 per cent of its initial value) in 24 hours.
The chief route of iodine elimination was in the urine. As shown by the solid line in the lower panel of Figure 3, 74 per cent of all iodine given was recovered in the urine in Group $B$ and the same percentage subsequently in Group A. In each man, excretion in considerable amounts continued through the third day after cessation of intake, but only in insignificant quantities thereafter. This delay in excretion prevented a useful calculation of daily yield, for, on the rest day of each week, in which little iodine was taken, there occurred nevertheless a fairly large iodine excretion (Figure 3 ). This lag was due to the iodine content of the extracellular fluid. To compensate for the lag, the device of calculating urine return in terms of a moving 7-day average was used. 
Thus in each 7-day average the excretion from 1 day in which the intake was low was included. This average yield is shown on the bottom panel of Figure 3 as a broken line. The decrease in per cent recovered in the urine which is apparent can be correlated with the increase in sweat output (weight loss) over the experimental period (Figure 5), and reflects the increased loss of iodine in sweat at high sweat outputs.

An attempt was made to obtain short-time measurements of the rate of iodine excretion in the urine in order to define the characteristics of urinary excretion as a function of plasma level and other factors. However, the tendency of all subjects to lag behind their water requirements during the period of active sweating led to low rates of urine flow and made accurately timed collections of urine very difficult. The available data indicated clearance rates from 10 to $25 \mathrm{ml}$. of plasma per minute with a tendency toward higher rates with increasing urine flow. Such clearances are consistent with the slopes of the plasma iodine disappearance lines in Figure 4.

The sweat was of next importance in the elimination of iodine. In Figure 6 it is apparent that sweat iodine concentration is related to plasma iodine concentration; roughly, the concentration of sweat iodine is 35 per cent of the concentration of plasma iodine. It can be seen that while the iodine level in arm sweat was of the same order of magnitude as the whole body sweat, it was nevertheless uniformly higher in relation to the

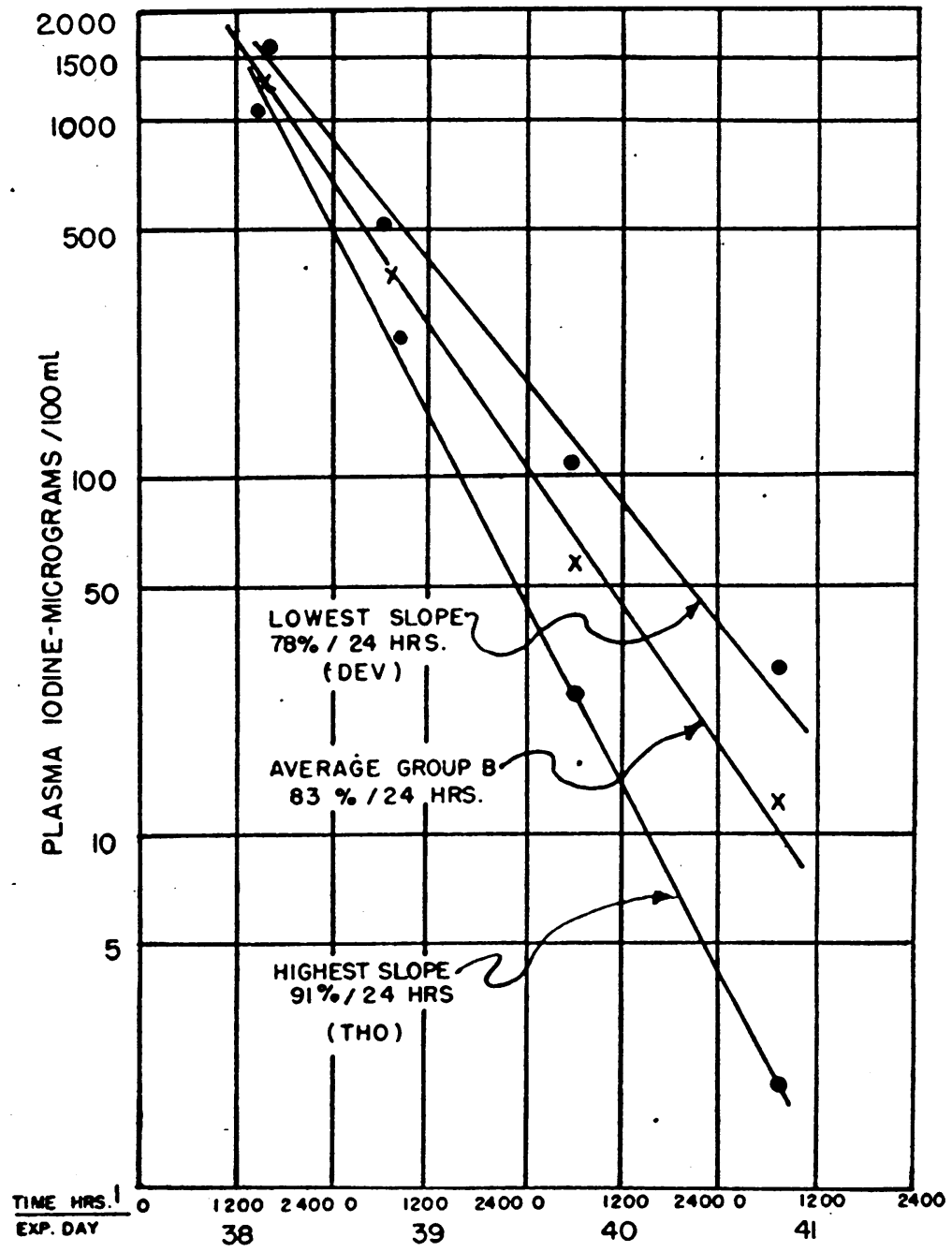

Fig. 4. Rate of Disappearance of Iodine from the Plasma (Group B) 
plasma level than whole body sweat by 25 per cent to 30 per cent. This may be due in part to regional differences in concentration.

Data pertinent to the question of analogy in sweat excretion between chloride and iodide were obtained in two experiments each on subjects Del and Bur. The results of these experiments are given in Table II. It appears that the concentration of both iodide and chloride in the sweat depends on the plasma concentrations in much the same way.

Relative to the amount ingested, only minor
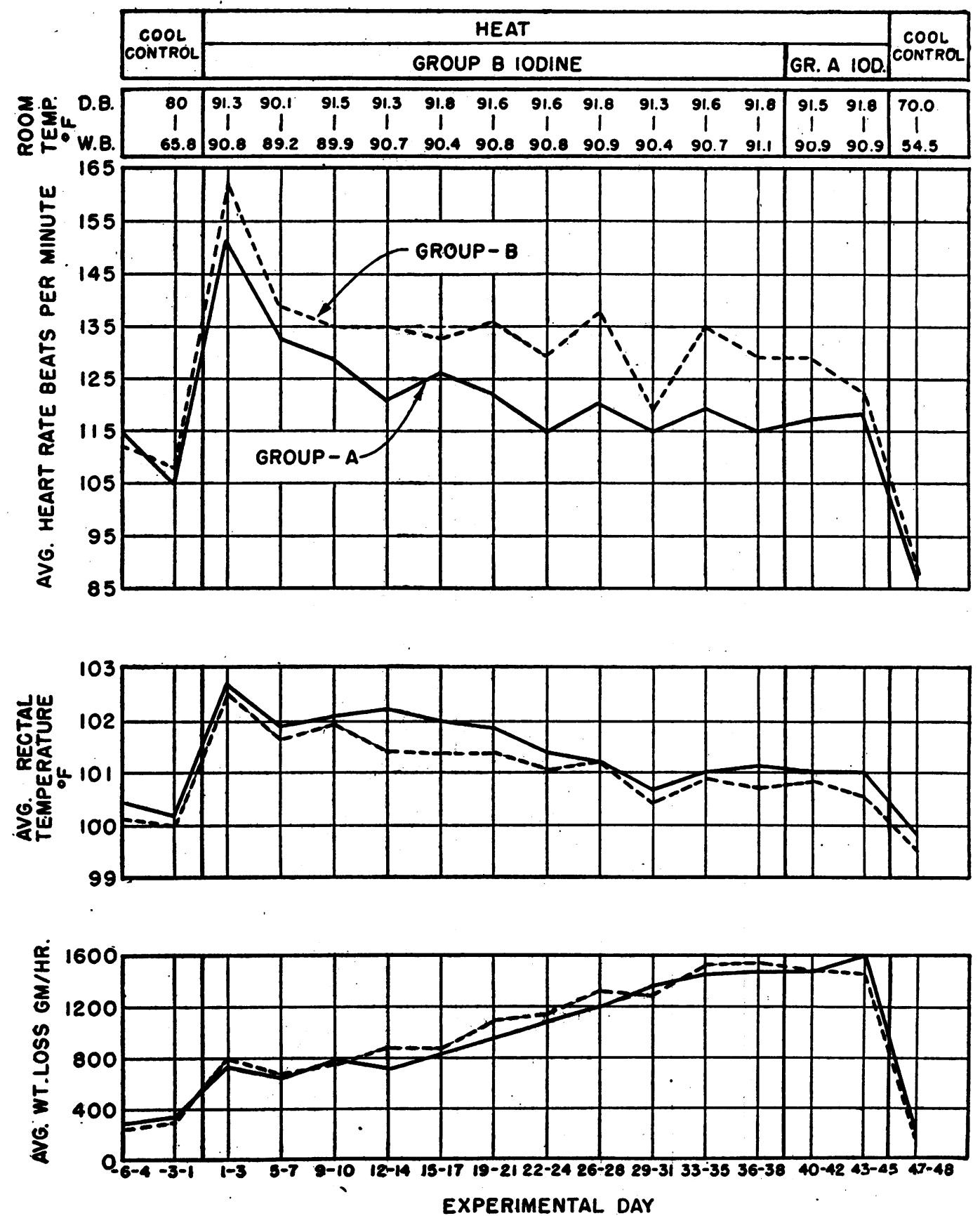

Fig. 5. Heart Rate, Rectal Temperature, and Hourly Weight Loss by 3-Day Periods 


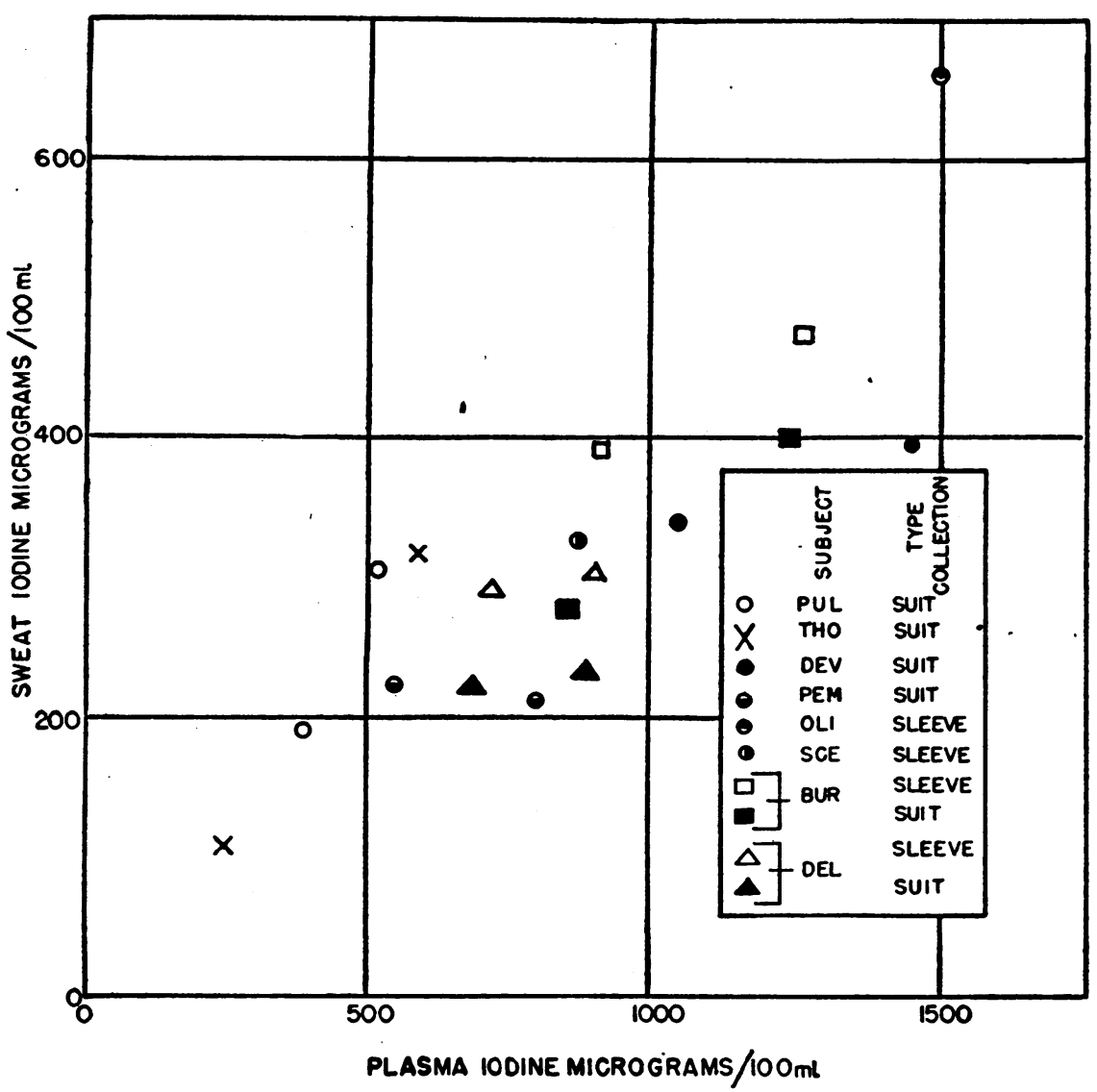

Fig. 6. Concentration of Iodine in Sweat as a Function of Plasma Iodine CONCENTRATION

amounts of iodine were found in the feces. Complete collections during 1 week made on subjects Pul and Tho led to recoveries of 0.32 per cent and 0.38 per cent respectively of ingested iodine.

Iodine balance. With the information available on the urine, sweat, and feces, it was possible to

\section{TABLE II}

Iodide and chloride excretion in the sweat as a function of plasma concentration

Arm sweat collected for 40-minute period; plasma values interpolated to midpoint of period

\begin{tabular}{|c|c|c|c|c|c|c|}
\hline \multirow{2}{*}{ Subject } & \multicolumn{3}{|c|}{ Iodide } & \multicolumn{3}{|c|}{ Chloride } \\
\hline & Plasma & Sweat & $\begin{array}{l}\text { Ratio } \\
I_{S} / I_{P}\end{array}$ & Plasma & Sweat & $\underset{\substack{\text { Ratio } \\
C l_{S} / C l_{P}}}{ }$ \\
\hline & $\underset{\text { per }}{\mu g .}$. & $\underset{\text { per } l .}{\text { Mg. }}$ & & $\begin{array}{l}\text { meq. } \\
\text { per } i .\end{array}$ & $\begin{array}{l}\text { meq. } \\
\text { per } i .\end{array}$ & \\
\hline $\begin{array}{ll}\text { Bur } & 1 \\
& 2 \\
\text { Del } & 1 \\
2\end{array}$ & $\begin{array}{r}910 \\
1,260 \\
720 \\
900\end{array}$ & $\begin{array}{l}3.94 \\
4.75 \\
2.95 \\
3.05\end{array}$ & $\begin{array}{l}0.433 \\
0.377 \\
0.410 \\
0.339\end{array}$ & $\begin{array}{r}95.5 \\
93.5 \\
101.7 \\
98.7\end{array}$ & $\begin{array}{l}41.5 \\
34.5 \\
36.8 \\
29.2\end{array}$ & $\begin{array}{l}0.434 \\
0.369 \\
0.362 \\
0.296\end{array}$ \\
\hline
\end{tabular}

assemble the partial balance shown in Table III. The basis of calculation of the various components was as follows: the intake and urine output were taken from the sources already mentioned; sweat iodine was calculated from the total sweat excretion and an estimated iodine concentration derived from the correlation in Figure 6 (Sweat $I=0.35$ plasma I, where plasma I was taken as $0.77^{\circ}$ average peak plasma concentration); fecal output was calculated as a percentage of the total intake based on the results from the subjects Tho and Pul of 0.38 per cent and 0.32 per cent respectively.

The resulting balance, though based on crude estimates, gives a fair picture of the relative importance of the various paths of iodine loss under the circumstances of this experiment.

5. The factor 0.77 was derived from curves of the type shown in Figure 1 to approximate an integrated average concentration for the work periods, the time of high sweat output. 
TABLE III

Approximate iodine balance

(See text for methods of estimation)

\begin{tabular}{|c|c|c|c|c|c|c|c|c|c|c|}
\hline \multirow{4}{*}{$\begin{array}{c}\text { Subject } \\
\text { SCE }\end{array}$} & \multirow{4}{*}{$\begin{array}{c}\text { Week } \\
\\
\\
2 \\
5 \\
\text { All }\end{array}$} & \multicolumn{9}{|c|}{ Iodine balance } \\
\hline & & \multirow{2}{*}{ In } & \multicolumn{8}{|c|}{ Out } \\
\hline & & & \multicolumn{2}{|c|}{ Urine } & \multicolumn{2}{|c|}{ Sweat } & \multicolumn{2}{|c|}{ Feces } & \multicolumn{2}{|c|}{ Total } \\
\hline & & $\begin{array}{r}m g m . \\
494 \\
1,675 \\
5,677\end{array}$ & $\begin{array}{r}m g m . \\
431 \\
1,475 \\
4,984 \\
\end{array}$ & \begin{tabular}{|c|} 
per \\
cent \\
87.3 \\
88.0 \\
87.8
\end{tabular} & $\begin{array}{r}m g m . \\
11 \\
69 \\
215\end{array}$ & $\begin{array}{l}\text { per } \\
\text { cent } \\
2.3 \\
4.1 \\
3.8 \\
\end{array}$ & $\begin{array}{r}m g m . \\
1.7 \\
5.9 \\
19.9 \\
\end{array}$ & $\begin{array}{l}\text { per } \\
\text { cent } \\
0.35 \\
0.35 \\
0.35 \\
\end{array}$ & $\begin{array}{r}m g m . \\
444 \\
1,550 \\
5,218\end{array}$ & \begin{tabular}{|l|} 
per \\
cent \\
89.9 \\
92.5 \\
91.9 \\
\end{tabular} \\
\hline THO & $\begin{array}{c}2 \\
5 \\
\text { All }\end{array}$ & $\begin{array}{r}550 \\
1,225 \\
5,699 \\
\end{array}$ & $\begin{array}{r}450 \\
1,008 \\
4,609 \\
\end{array}$ & \begin{tabular}{|l|}
81.8 \\
82.3 \\
80.9
\end{tabular} & $\begin{array}{r}17 \\
79 \\
337\end{array}$ & $\begin{array}{l}3.0 \\
6.5 \\
5.9 \\
\end{array}$ & $\begin{array}{r}1.9 \\
4.3 \\
20.0\end{array}$ & \begin{tabular}{|l|}
0.35 \\
0.35 \\
0.35 \\
\end{tabular} & $\begin{array}{r}469 \\
1,092 \\
4,966\end{array}$ & \begin{tabular}{|l|}
85.1 \\
89.1 \\
87.1 \\
\end{tabular} \\
\hline DEV & $\begin{array}{c}2 \\
5 \\
\text { All } \\
\end{array}$ & $\begin{array}{r}895 \\
1,623 \\
7,460 \\
\end{array}$ & $\begin{array}{r}690 \\
1,197 \\
4,904 \\
\end{array}$ & \begin{tabular}{|l|}
77.1 \\
73.8 \\
65.7 \\
\end{tabular} & $\begin{array}{r}37 \\
153 \\
575 \\
\end{array}$ & $\begin{array}{l}4.2 \\
9.4 \\
7.7 \\
\end{array}$ & $\begin{array}{r}3.1 \\
5.7 \\
26.1 \\
\end{array}$ & $\begin{array}{l}0.35 \\
0.35 \\
0.35\end{array}$ & $\begin{array}{r}730 \\
1,356 \\
5,504\end{array}$ & \begin{tabular}{|l|}
81.6 \\
83.5 \\
73.8
\end{tabular} \\
\hline $\begin{array}{l}\text { Group B } \\
\text { (10 Men) }\end{array}$ & $\begin{array}{c}2 \\
5 \\
\text { All }\end{array}$ & $\begin{array}{r}804 \\
1,621 \\
7,143\end{array}$ & $\begin{array}{r}691 \\
1,157 \\
5,283\end{array}$ & \begin{tabular}{|l|}
85.9 \\
71.4 \\
73.9
\end{tabular} & $\begin{array}{r}24 \\
117 \\
430\end{array}$ & $\begin{array}{l}3.0 \\
7.2 \\
6.0\end{array}$ & \begin{tabular}{|r|}
2.8 \\
5.7 \\
25.0
\end{tabular} & \begin{tabular}{|l|}
0.35 \\
0.35 \\
0.35
\end{tabular} & $\begin{array}{r}718 \\
1,280 \\
5,738\end{array}$ & \begin{tabular}{|l|}
89.3 \\
78.9 \\
80.3
\end{tabular} \\
\hline
\end{tabular}

Physiological effects. The subjects ingested an average of $88 \mathrm{mgm}$. of iodine daily and attained blood plasma concentrations ranging from 75 to $1,300 \mu \mathrm{g}$. per $100 \mathrm{ml}$. during the 38-day period of exposure (Figure 3 ).

No deleterious effect on performance of work and no unusual hardships during acclimatization to heat were noted in those men taking iodine when compared with the control group or in comparison with other groups of normal subjects under similar conditions of stress $(35,36)$. The measurement of final postwork heart rate, rectal temperatures, and hourly sweat rates for the control and test periods are presented in Figure 5. It is apparent that the responses of both groups of men were parallel, regardless of the intake of iodine.

The results of the basal metabolism tests are presented in Figure 7 . The group averages showed no trend, nor was any trend noted in the analysis of the results of individual subjects. No apparent change in basal metabolic rate due to heat exposure alone under the conditions of this experiment could be found. No change was observed in the size or consistency of the thyroid gland, and the neck circumference did not alter. There was an insignificant weight loss in both groups.

Blood and urine examinations before and after exposure to heat and iodine revealed only a slight fall in blood hemoglobin, similar to that noted in other groups of subjects exposed to heat alone.

The general symptomatology of the men in both groups was similiar and was that of acclimatization as has been described elsewhere (35. 36). Blood pressure measurements were not remarkable. Of

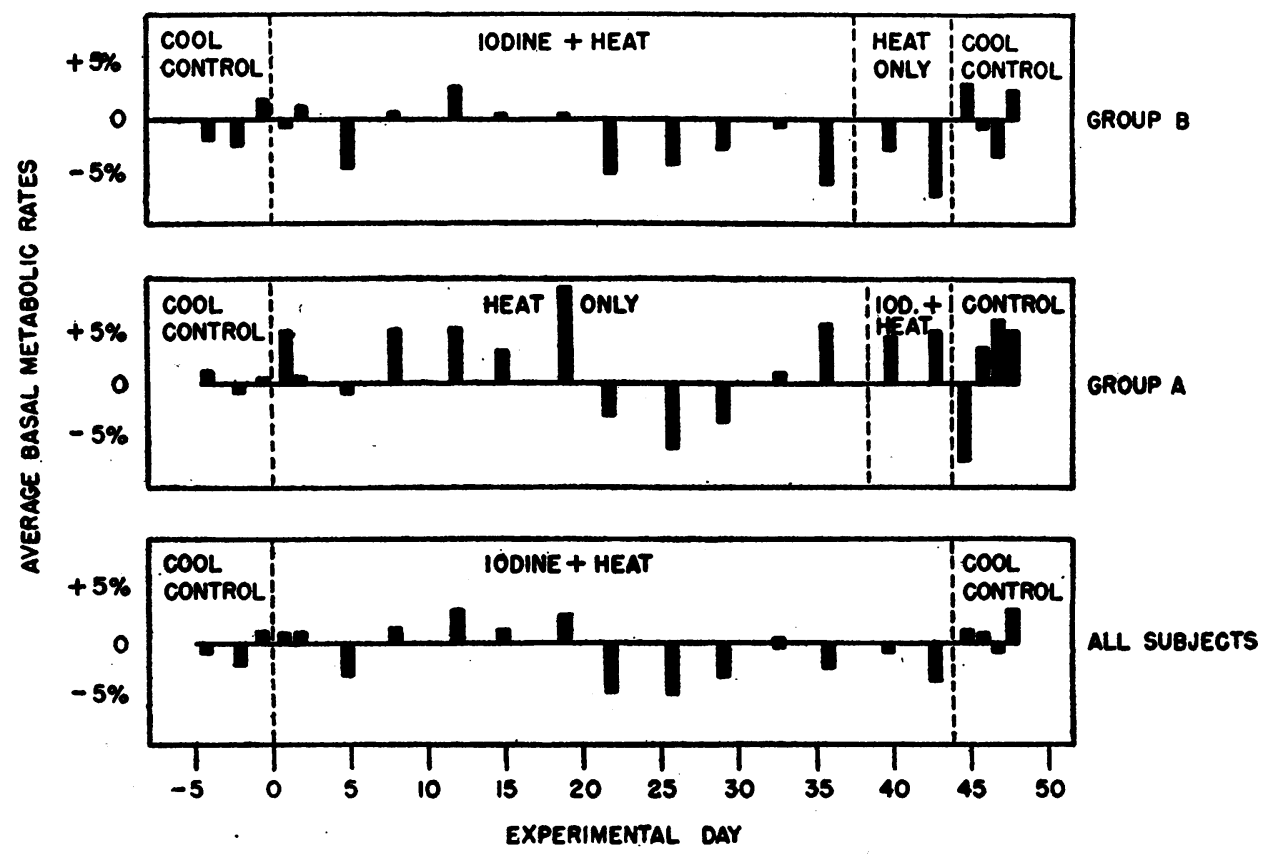

Fig. 7. Effect of Iodine and Heat on the Basal Metabolic Rate 
incidental interest was the fact that the taste of iodine water, found quite disagreeable at first, was preferred by the subjects to salted tap water at the end of the period of exposure.

The men were tested for skin sensitivity to iodine during and at the conclusion of the experiment but the small number of subjects precluded drawing any useful conclusions in that regard.

\section{SUM MARY}

(1) Inorganic iodine was rapidly and completely absorbed from the gastrointestinal tract.

(2) The plasma concentration of iodine was directly proportional to the quantity ingested.

(3) The iodine plasma level fell rapidly after cessation of iodine intake reaching near basal levels within 72 hours.

(4) Excretion of iodine was chiefly in the urine but an appreciable fraction appeared in the sweat. Sweat iodine concentration was 35 per cent of plasma concentration. Fecal excretion was negligible.

(5) No effect on general health, acclimatization to heat, vital signs, basal metabolism, blood, or urine could be ascribed to the ingestion of iodine by normal subjects over a period of 6 weeks.

We wish to thank T. C. Swigert, J. L. Gray, R. J. Bloom, and F. W. Urbush for technical assistance.

\section{BIBLIOGRAPHY}

1. Cole, V. V., and Curtis, G. M., Iodine metabolism of adult rat in relation to trauma, thyroid activity and diet. J. Pharmacol. \& Eper. Therap., 1936, 56, 351.

2. Elmer, A. W., Iodine Metabolism and Thyroid Function. London, Oxford University Press, Humphrey Milford, 1938.

3. Mann, W., Leblond, C. P., and Warren, S. L., Iodine metabolism of the thyroid gland. J. Biol. Chem., 1942, $142,905$.

4. Salter, W. T., The Endocrine Function of Iodine. Cambridge, Mass., Harvard University Press, 1940.

5. Hamilton, J. G., Rates of absorption of radioactive isotopes of sodium, potassium, chlorine, bromine, and iodine in normal human subjects. Am. J. Physiol., 1938, 124, 667.

6. Orr, J. B., and Leitch, I., Iodine in Nutrition. A Review of Existing Information. Med. Res. Council Special Report, Series 123. London, 1929.

7. Cole, V. V., and Curtis, G. M., Human iodine balance. J. Nutrition, 1935, 10, 493.
8. Fellenberg, $T$. von, Research on iodine metabolism. Biochem. Ztschr., 1926, 174, 341.

9. Scheffer, L., Jodgehalt der Nahrung und Kropfhäufigkeit. .Biochem. Ztschr., 1932, 247, 418.

10. Rawson, R. W., Moore, F. D., Peacock, W., Means, J. H., Cope, O., and Riddell, C. B., Effect of iodine on the thyroid gland in Graves' disease when given in conjunction with thiouracil-a two-action theory of iodine. J. Clin. Invest., 1945, 24, 869.

11. Goodman, L., and Gilman, A., The Pharmacological Basis of Therapeutics. New York, Macmillan, 1941.

12. Seymour, W. B., Jr., Poisoning from cutaneous application of iodine; rare aspect of its toxicologic properties. Arch. Int. Med., 1937, 59, 952.

13. Barker, W. H., and Wood, W. B., Severe febrile iodism during the treatment of hyperthyroidism. J. A. M. A., 1940, 114, 1029.

14. Finkelstein, R., and Jacobi, M., Fatal iodine poisoning; a clinico-pathologic and experimental study. Ann. Int. Med., 1937, 10, 1283.

15. Liebesny, P., Beitraege zur Pathologie des respiratorischen Gaswechsels. III. Mitteilung. Ueber den Einfluss des Jods auf den Stoff wechsel. Wien. klin. Wchnschr., 1924, 37, 521.

16. Veil, W. H., and Sturm, A., Beitraege zur Kenntnis des Jodstoffwechsels. Deutsches Arch. f. klin. Med., 1925, 147, 166.

17. Crotti, A., Thyroid and Thymus. Lea and Febiger, Phila., 1918.

18. Martin, K. A., Conditions under which iodine will cause change in basal metabolic rate in man; its occurrence in conditions other than that of Graves' disease. Am. J. M. Sc., 1927, 174, 648.

19. Snell, A. M., Ford, F., and Rowntree, L. G., Studies in basal metabolism. J. A. M. A., 1920, 75, 515.

20. Strouse, S., and Binswanger, H. F., Symptom complex resembling hyperthyroidism without increased metabolism; preliminary report. J. A. M. A., 1927, 88, 161.

21. Means, J. H., and Richardson, E. P., The Diagnosis and Treatment of Disease of the Thyroid. New York, Oxford University Press, 1938.

22. Kimball, O. P., Iodized salt for the prophylaxis of endemic goiter. J. A. M. A., 1946, 130, 80.

23. Webster, B., and Chesney, A. M., Endemic goitre in rabbits; effect of administration of iodine. Bull. Johns Hopkins Hosp., 1928, 43, 291.

24. Loeser, A., Die Umstimmung der Schilddrüsentätigkeit durch Jod. Klin. Wchnschr., 1934, 13, 533.

25. Siebert, W .J., and Linton, C. S., Comparison of effects of potassium iodide and of diiodotyrosin upon basal metabolism. J. Pharmacol. \& Exper. Therap., 1935, 53, 418.

26. Siebert, W. J., Effect of KI upon basal metabolism and respiratory quotient in thyroidectomized guinea pigs. Proc. Soc. Exper. Biol. \& Med., 1932, 29, 1146. 
27. Rabinovitch, J., Effect of feeding potassium iodide on proliferative activity of thyroid gland in guinea pigs. Am. J. Path., 1928, 4, 601.

28. Marine, D., Deutch, M., and Cipra, A., Effect of large doses of iodine on heat production in rabbits. Proc. Soc. Exper. Biol. \& Med., 1927, 24, 657.

29. Grabfield, G. P., and Prentiss, A. M., Further studies on effect of iodides on human nitrogen metabolism. J. Pharmacol. \& Exper. Therap., 1925, 25, 411.

30. Nelson, N., Palmes, E. D., and Weymouth, P. P., Determination of iodine in biological materials. To be published.

31. Wallace, G. B., and Brodie, B. B., Distribution of administered iodide and thiocyanate in comparison with chloride, and their relation to body fluids. J. Pharmacol. \& Exper. Therap., 1937, 61, 397.
32. Trevorrow, V., Studies on the nature of the iodine in blood. J. Biol. Chem., 1939, 137, 737.

33. Man, E. B., Smirnow, A. E., Gildea, E. F., and Peters, J. P., Serum iodine fractions in hyperthyroidism. J. Clin. Invest., 1942, 21, 773.

34. Cohn, B. .N. E., Absorption of compound solution of iodine from gastrointestinal tract, with special reference to absorption of free iodine. Arch. Int. Med., 1932, 49, 950.

35. Bean, W. B., and Eichna, L. W., Performance in relation to environmental temperature. Federation Proc., 1943, 2, 144.

36. Eichna, L. W., Bean, W. B., Ashe, W. F., and Nelson, N., Performance in relation to environmental temperature. Bull. Johns Hopkins Hosp., 1945, 76, 25. 